\title{
Business models transformed by digitalization in contemporary art museums and galleries
}

\begin{abstract}
In the $21^{\text {st }}$ Century, the common features of the developing digital technology are compressed information, accelerated information management, big data, multiple interaction, personalization and uninterrupted access and convergence. These features are seen as factors that accelerate access to information, reduce some communication and cost expenses economically, speed up sales and marketing, provide visibility to institutions, and increase ideas and sharing. With the effects of digital technology Contemporary art museums and galleries have experienced digitalization processes in order to maintain their existence and achieve their goals. Digitalization is not limited to being a technical application, but it is a process that transforms contemporary art institutions as a whole, especially in communication, institutionalism, branding, marketing, finance and sustainability. Therefore, digital technology requires to be available to institutions. Being a contemporary art institution requires being intellectually and technologically renewed in institutional, managerial and communicative terms. The mission and sustainability of art and art institutions should be ensured in harmony with technology. Therefore, new business models have been required in the digitalization processes in art institutions and the need for changing business models will increase as technology develops. Purpose of the study: To identify the new business models of contemporary art museums and galleries, and in parallel, the features they need in human resources, and to raise awareness on this issue. In this study, the hybrid structure of new business models needed in contemporary art institutions has been revealed as a whole. In the study, it has been revealed based on the examples and the viewpoints of authorized persons that, managerial digital strategies in contemporary art museums and galleries should contain the distinction specific to art. The main result that emerged from the interviews is the hybrid structures of the new business models needed by contemporary art museums and galleries in the digital age, blended with digital technology and the knowledge of art management.
\end{abstract}

\author{
Atiye Güner ${ }^{1}$ (1) \\ İsmail Erim Gülaçt' ${ }^{2}$ \\ ${ }^{1}$ Yıldız Technical University, Student \\ in Art and Design PhD Programme, \\ İstanbul Turkey \\ Hasan Kalyoncu University, \\ Faculty of Communication, \\ Visual Communication Design \\ Department, Gaziantep, Turkey \\ ${ }^{2}$ Yıldız Technical University, \\ Faculty of Art and Design Department \\ of Art, İstanbul Turkey
}

Corresponding author:

Atiye Güner

e-mail: atiye.gll@gmail.com

First recieved: 25.10.2021.

Accepted: 17.11.2021.

\section{KEY WORDS}

Digital technology, contemporary art museums, contemporary art galleries, digital strategy, digital business models in art Institutions

\section{Introduction}

In the $21^{\text {st }}$ century, the continuously evolving nature of digital technology and digitalization processes have canalized business models into a direction that requires digital competencies. As well as the yields of digital technology, contemporary art institutions are surrounded by areas such as global competition, institutionalization requirements, and creating a contemporary art environment. Therefore, it can be argued that these 
institutions are directly related to management, communication, marketing, sociology, informatics disciplines, art history, art criticism and need digital competencies in all these subjects. For example, contemporary museology has an understanding that envisages new business models for museum staff in many fields such as creating collections, exhibiting, preparing archives, museum management, museum marketing, preservation, and storage (Karadeniz, 2018:pp.78-79).

In addition, as Yücel asserts, as institutionalization becomes faster, accurate, powerful, and systematic, the fields of expertise increase more. As the service areas of contemporary art museums and galleries diversify and institutionalization gets strong, specialization will increase. The need for new business models will increase.

The widespread use of IT and rapidly developing digital technology have caused museums and some galleries to define new business models that require digital skills such as experience director and digital director. According to Borusan Contemporary manager Kumru Eren it is necessary to gather the areas where new business lines are needed under three main headings as the presentation of exhibitions and works, commercial activities, and communication. First of all, with the development of technology, works that are only visually displayed on the internet can now be visited in virtual tour format of the exhibition spaces by laser scanning method.

The development of technology has enabled the works to be experienced more comprehensively with Augmented Reality and Virtual Reality technologies and the use of these technologies in the production of works. Moreover, the integration of voice guide applications into mobile devices provides a more comfortable experience for visitors. Also, the development of electronic commerce and the developing electronic marketplaces bring the products offered by contemporary art museums and galleries to the wider masses.

Finally, the increase in the number of social platforms and the differentiation of their offered content structures also require institutions to produce communication and marketing content that will appeal to diverse audiences. Within this context, it can be maintained that new business lines have appeared for the provision of all these services.

\section{Method}

This study is examined in six sections. The introduction provides information about the research subject. In the second part, the method of the research is emphasized. In the third part, the importance of digital strategy applications in the managerial field of contemporary art museums and galleries is scrutinized.
In the fourth chapter, the literature is reviewed, and the works requiring digital competence that contemporary art museums and galleries need are discussed through the studies carried out on this subject. In the fifth section, the data obtained from the interviews with the contemporary art museums and galleries, which constitute the sample of the study, are examined by the content analysis method. In the conclusion part, a conclusion is held out in light of all the findings.

The Qualitative research method was used as the method, and in-depth interviews were conducted with the managers of contemporary art museums and galleries, which were determined as samples, via e-mail or digital platform. Qualitative research is research in which qualitative data collection methods such as observation, interview, and document analysis are used, and a qualitative process is followed to reveal perceptions and events in a natural environment in a realistic and holistic way (Yıldırım \& Şimşek, 2006:p.39).

The institutions that constitute the sample of the study are Akbank Art, Arter, Arton, Baksı Museum, Borusan Contemporary, Elgiz Museum, Kasa Gallery Pi-artworks, Pera Museum, and Zilberman Gallery selected from Turkey. Interviews with the managers of these institutions will be presented as an appendix to Atiye'Güner's doctoral thesis titled The Effects of Digitalization on Contemporary Art Museums and Galleries, which forms the basis of this study.

The interviewers and interview dates from the sample institutions are as follows. Hüsamettin Koçan the founder and general director of Baksı Museum (13.07.2021), Firdevs Ev Şimşek the media and marketing officer and Behiye Bobaroğlu collection manager of Arter (29.07.2021), Oktay Duran the founder and general manager of Art On Gallery (30.06.2021), Kumru Eren the managing director of Borusan Contemporary (26.072021), Ayda Elgiz Güreli founder and the managing director of Elgiz Museum (19.08.2021), Derya Yücel the managing director of the Kasa Gallery (16.06.2021) Özalp Birol the general manager of Pera Museum (26.05.2021, Moiz Zilberman: owner and general manager of Zilberman Gallery (30.06.2021), Eda Derala Pi art Works gallery manager (25.06.2021), Director of Akbank Art Curator Zeynep Arınç (21.06.2021).

In the meeting; The following questions were asked to the interviewees: Which new business models are needed in art institutions with digitalization. How has your institution been affected by this? The answers received were analyzed by content analysis and descriptive analysis methods. A code name was given to each of the interviewers in the analysis table. The analysis will appear in Table 1 in the Finding And Discussion section. In addition, studies conducted in this direction in the literature were also examined. 


\section{The importance of digital strategies in contemporary art institutions}

Two general approaches can be identified in digital transformation strategies. The first is the presence of digital talents within the company and the employment of sufficient IT specialists. This strategy can be described as defensive. Developing the digital literacy level of staff is imperative and it is a strategy that is oriented to maintain old activities on the basis of new technologies, rather than using the full potential of new technologies. In other words, this strategy is utilized to enhance the ongoing activities of digital technologies. The second strategy towards digitalization is to develop new products, processes, and business models using the innovative and disruptive features of digital technologies (Taymaz, 2018:pp.19-20). Although the successful implementation of this strategy is much more difficult than the defensive strategy, its economic and social returns are remarkably higher. In order for this strategy to be successful, it is necessary to develop innovative talents within the company and to actively participate in international innovation networks.

It can be stated that in the digitalization processes, the necessity of digital strategies in the administrative field for contemporary art institutions has emerged. The digital strategy to be implemented in the administrative field is fed through two channels: financial resources and leadership that can manage change (Krebs, 2016). The purpose of a digital strategy is a vision statement with objectives for the organization's digital programs, supported by adequate 'evidence-based' leadership resources, and utilized as a guide by management and operations (Morrison, 2019:p.15). To put it more simply, the purpose of the digital strategy is a vision and goal expression for the organization's digital programs, and it is essential to inform all employees and collaborators about the potential and benefits that digital technology can create in corporate governance and operations.

Digital strategy for art museums and art institutions is different from other types of strategies. The digital environment is volatile due to the rapid change in technology. Therefore, unlike other departments, strategic plans need to be regularly and radically reviewed, along with the digital programs offered by the digital operation (Morrison, 2019:p.3). Differences between museums and galleries may not be appropriate for the same type of strategy. Their financial instruments, sizes, missions, places where they position themselves on the global scale, and target audiences are different. For this reason, it can be asserted that different types of strategies are required for digitalization in contemporary art institutions.
Krebs (2016:pp.56-61), Head of the Socio-Economic Studies and Research Division at the Louvre Museum's Research and Collection Department, draws attention to the fact that many museums try to develop crowdfunding programs using digital tools to improve or develop their restoration or education programs. However, there is a very strong digital difference between museums, depending on their size, financial instruments, and digital capabilities. Museums should generate a solution to this phenomenon in order to ensure their sustainability. First, the problem of digital competencies should be analyzed on a regional or local scale. According to Krebs (2016:pp.58-59), in terms of digital competencies, there is a big difference between white-collar and blue-collar workers, for example between administrators and gallery staff. Museums should organize seminars to develop digital skills, as the Louvre does, and try to eliminate inequality.

The exact scope of digital may vary from one organization to another. Unlike many other industrial sectors, museums have routes of reaching their target audience both during a visit and through online digital media. Providing people with a unified experience before, during and after a museum visit is an interesting strategic opportunity. For most purposes, and for most organizations, the starting point for digital definition and a unified experience can be any public digital service, including kiosks, digital signage, internal digital transactions websites, apps, and social media accounts, and all processes that directly support them (Morrison, 2019:p.14). The same remarks can be made for a contemporary gallery. It is possible to argue that the digital strategy is not only a strategy for museums and galleries but also a local and unified perspective and network for the preservation and digitalization of the collection and the digital skills of professionals.

The digital strategy of museums and galleries depends on several factors, such as financial resources, and leadership that can manage change. Therefore, implementing a strategy related to digital strategy and digital competencies in art institutions such as museums and galleries is both necessary and difficult. Krebs (2016:p.57) articulates this challenge as linked to the general economic model of museums. The application of digital technologies and methods is necessary to engender the digital strategies of museums/galleries.

However, the impact of the introduction of digital tools into the museum/gallery sector on the workforce and economic models of museums and galleries is also a crucial question. Expeditious changes in the media and technology environment require financial resources for museums and galleries. Rapid changes in the media and technology environment make a certain type of strategic response necessary (Morrison, 2019:p.18). For example, it is possible to be agile and responsive in 
changing areas, e.g., devices and interfaces, while investing in permanent foundations such as content infrastructure and capacity. Contemporary art institutions should generally deliver a very high-quality customer experience in the field. If a museum or gallery is failing to keep up with technological change and providing a poor online customer experience, it risks damaging its reputation with key stakeholders and customer groups.

According to Resch (2018:pp.89-92), art gallery management and most galleries are stuck with a communication concept based on regular news bulletins and advertisements in art newspapers and traditional methods, which fails to produce the expected added value. Customers in certain segments want clarity and transparency, low risk and personalized offers tailored to their motives. The solution to this problem can be found in galleries' usage of functional customer relationship management (CRM) technology such as Artbinder. com, Gallerymanager.com, and tailoring their marketing messages to target the right customer with the correct value proposition. Customer relationship management (CRM) is a system that has become widespread since the late 1990s, keeping customer information in a central database, enabling the identification of customers (and their needs), thus enabling the development of customer-specific applications (Taymaz, 2018:p.93). Software systems not only help to organize effective personalized approaches for clients but also can ease the workload associated with digital photos, biographies, press releases, catalogues, invoicing and PR tasks.

As emphasized by Kati Price (Price, 2016:pp.110-11), the Head of Digital Media and Publishing at the Victoria \& Albert Museum, the website, virtual commerce, CRM, collection management and digital data management system, social media management are the domains which the main investment and resources should be allocated for a museum. Only through this parallel, one can build a persuasive digital experience that needs to be tailored to her/his organization.

Regarding museums, according to Erbay (2017:p.267), museums, the business world and educational institutions can be expected to work together in the future. Contemporary museology will have to change its management styles, business situations, institutional needs, contracts and business models according to the needs of the new generation. With respect to galleries, the increasing complexity of the art market, due to the competition of galleries with each other and with other institutions in the art market, requires an open organizational structure (Resch, 2018:p.53). Galleries should define clear roles, job positions, adopt the technology necessary to improve these processes and accelerate business exercises and propound their digital strategies. The business models proposal propounded for contemporary art museums can also be applied to contemporary art galleries.

\section{Business areas requiring digital competence in contemporary art museums and galleries}

Today, contemporary art museums are not only institutions that transmit information, protect, seek information, and serve the spread of culture and art. A contemporary art museum is a variety of curatorial projects, guided tours, screenings, conferences, performances, etc., organized for the purpose of education, training, entertainment, where the audience is involved in art events. It is like a multifunctional show venue where products are marketed as commercial enterprises (Birol, 2018). Contemporary art museums play a vital role in the economy and cultural tourism and compete in the leisure industry (Belenioti \& Vassiliadis, 2017:p.115). In this respect, it is seen that contemporary art museums are in an interdisciplinary structure covering the fields of marketing, art management, communication, and informatics. This interdisciplinary structure has expanded the need for different business models and the rapid development in information technology has increased the significance of digital competencies.

During the interview conducted with Özalp Birol, the director of Pera Museum, it is expressed that in terms of both the activities of the institutions and the work patterns in the office, with the development and enrichment of the existing business model for museums by using digital opportunities, a new model which can be called hybrid has emerged which blends physical access with digital/virtual access. Herein, several examples are indicated, such as exhibitions that provide 3D virtual tours, digital exhibitions, conferences held on online platforms, symposiums, learning and film programs, transferring selected publications to digital media, changing office working hours, and the possibility of working remotely with digital access.

Today, it can be asserted that art galleries have similar functions with museums as institutions where works of art are exhibited, where they meet with visitors, are archived, create sectoral memories, and provide social benefits. In the report compiled within the scope of the Istanbul Cultural Heritage and Cultural Economy Inventory 2010 (Istanbul Kültür Mirası ve Kültür Ekonomisi Envanteri 2010) Project (Bakbaşa \& Plancisi, 2017:p.7), the value production chain for the visual arts sector was constructed. In the report, art galleries and museums are in the same category as one of the crucial distribution domains in the visual arts sector. According to the report, art galleries were not only evaluated as sectoral initiators but also as actors that ensure the formation and trans- 


\section{Table 1}

Job Areas Requiring Digital Competence (Mu.SA - Museum Sector Skills Alliance, 2017:pp.36-37)

\begin{tabular}{|c|c|}
\hline Business Model Mission: & $\begin{array}{l}\text { Digital Strategy Manager, she/he can also be defined as BIT consultant. Digital Strategy } \\
\text { Managers reinforce a museum's technological and digital innovation. She/he is responsible } \\
\text { for a digital transformation plan in accordance with the general museum strategy. Alongside } \\
\text { the entire museum management, she/he is responsible for the top-level museum digital } \\
\text { strategy and financial planning of technological resources. She/he plays a mediating role } \\
\text { between internal museum departments and external stakeholders and can communicate } \\
\text { effectively with a variety of different stakeholders, especially high-tech companies. }\end{array}$ \\
\hline Business Model Mission: & $\begin{array}{l}\text { Digital Cultural Asset Manager, Digital Asset Manager, Digital Curator, The Digital } \\
\text { Collections Curator is responsible for implementing the digital strategy of collecting, } \\
\text { storing, archiving, preserving, and making available digital collections. }\end{array}$ \\
\hline Business Model Mission: & $\begin{array}{l}\text { Digital Interactive Experience Builder, Interactive Experience Builder, Digital } \\
\text { Interactive Experience Designer, Interactive Exhibition Designer, } \\
\text { Digital Interactive Experience Builder designs, develops and implements innovative and interactive } \\
\text { experiences based on audience needs, providing meaningful experiences for all types of audiences. }\end{array}$ \\
\hline Business Model Mission: & $\begin{array}{l}\text { Online Community Manager; Online Cultural Community Manager, Digital Communications } \\
\text { Manager, Digital Media Curator, Visual Media Curator, New Media Manager, Social Media } \\
\text { Specialist or Online Community Developer. The online community manager responds to } \\
\text { the needs of both online and offline communities. Builds and manages accessible and } \\
\text { collaborative online communities for all stakeholders (audience, colleagues in museums and } \\
\text { the heritage sector, educational organisations, donors, sponsors, decision-makers, etc.) }\end{array}$ \\
\hline \multicolumn{2}{|r|}{ Adapted from pp. 36-37 of Mu.Sa Report. Emerging Job Profiles for museum professionals } \\
\hline
\end{tabular}

mission of contemporary art memory. This detection designates that today's contemporary art museums and galleries have different aspects, but they have the same motivation and mission and they are akin in terms of their functions. It can be claimed that the new business models that contemporary art museums and galleries require in their digitalization processes are alike.

According to the results of the Mu.SA: Museum Sector Alliance research platform eCult Skills project carried out between 2016-2019, four job profiles that require digital competencies have been identified for museum staff (Mu.SA - Museum Sector Skills Alliance, 2017). Business profiles ascertained for the success of museums in their digital transformation are Digital Strategy Manager, Digital Collections Curator, Digital Interactive Experience Developer, and Online Community Manager. In Table 1 , business models that require digital competence and the missions of business models are delineated.

The changing business models in the galleries arose from the demands of gaining a place in the global market with the effects of globalization, competing and constituting a brand identity within this context. Changing aims and functions of galleries required them to be managed professionally. In this context, the above-mentioned differences between traditional art galleries, and new galleries that adapt to modernization are illustrated in Table 2. This difference is exhibited to explain the new business models that galleries need.

\section{Table 2}

Difference between Traditional and Contemporary Galleries (Resch, 2018)

\begin{tabular}{|c|c|c|}
\hline Value Suggestion & Sale of Art Works & $\begin{array}{l}\text { A Complete Range } \\
\text { of Services }\end{array}$ \\
\hline $\begin{array}{l}\text { Customer } \\
\text { Concept }\end{array}$ & $\begin{array}{l}\text { 1. Art lover } \\
\text { 2. Corporate } \\
\text { collector } \\
\text { 3. Seller/Collector }\end{array}$ & $\begin{array}{l}\text { Customer } \\
\text { segmentation } \\
\text { in three groups } \\
\text { (Flamboyant, } \\
\text { amateur, traditional) }\end{array}$ \\
\hline $\begin{array}{l}\text { Communication } \\
\text { Concept }\end{array}$ & $\begin{array}{l}\text { Traditional Channels } \\
\text { (mail, e-mail, } \\
\text { announcements) }\end{array}$ & $\begin{array}{l}\text { Brand building, } \\
\text { digital technologies }\end{array}$ \\
\hline Income Concept & Sale of artworks & $\begin{array}{l}\text { Attractive pricing } \\
\text { Keeping costs low }\end{array}$ \\
\hline Growth Concept & $\begin{array}{l}\text { No concept } \\
\text { of growth }\end{array}$ & Global prevalence \\
\hline $\begin{array}{l}\text { Competency } \\
\text { Configuration }\end{array}$ & $\begin{array}{l}\text { Authority in } \\
\text { art history }\end{array}$ & $\begin{array}{l}\text { Marketing and sales } \\
\text { management }\end{array}$ \\
\hline Organization Type & $\begin{array}{l}\text { Focus on primary } \\
\text { market; } \\
\text { Gallery managers } \\
\text { and assistants }\end{array}$ & $\begin{array}{l}\text { Three-stage } \\
\text { structure: } \\
\text { storehouse, } \\
\text { gallery, fine arts }\end{array}$ \\
\hline $\begin{array}{l}\text { Institution } \\
\text { Concept }\end{array}$ & $\begin{array}{l}\text { Artists and other } \\
\text { galleries }\end{array}$ & $\begin{array}{l}\text { Long-term } \\
\text { relationships with } \\
\text { arts and non-art } \\
\text { organizations }\end{array}$ \\
\hline $\begin{array}{l}\text { Coordination } \\
\text { Concept }\end{array}$ & $\begin{array}{l}\text { Uncertain market } \\
\text { processes without } \\
\text { contract }\end{array}$ & $\begin{array}{l}\text { Contracts with all } \\
\text { partners, continuous } \\
\text { revision of these } \\
\text { relationships }\end{array}$ \\
\hline
\end{tabular}


According to new gallery understandings, competencies are quite important as the adoption of strong management principles increases professionalism in the art sector. Managers should be professionals who demonstrate both management knowledge and business ethics (Resch, 2018:p.53). To illustrate, typical blue-chip gallery staff consists of; sales directors, gallery partners, artist contacts, registrars, archivists, accountants, and a preparation/installation team. Galleries may also hire full-time staff or contract freelancers to assist with photography and marketing (Bunting, Allison \& Handler, 2014:p.82). Sales directors, called gallerists, are responsible for the exhibition plans of the galleries, all the communication and educational projects of the galleries, and communication with the artists. Their duties are not limited to these, but they set relationships with customers and the public about the work of artists (Bunting, Allison \& Handler, 2014:p.82). It can be supposed that they have a similar role to the curators in the museum and have the primary responsibility for communication within all areas. One of the most prominent functions of galleries is that they represent a group of artists of their choice. In addition to exhibiting and selling works of art, they are responsible for the representation and promotion of a group of artists of their choice (Bunting, Allison \& Handler, 2014:p.85). It is also one of the functions of the galleries to organize educational curatorial works, including the work of the artist. To further this mission, galleries perform crucial tasks such as storing and maintaining artworks, lending to museum exhibits, sending works to other galleries, providing an image to the press and collectors, maintaining an artist's resume and bibliography, creating educational films, setting catalogs and prices (Bunting, Allison \& Handler, 2014:p.81). All of these events create archive records that are actively used for the representation of artists. When pre-presenting gallery recordings for easy access, the gallery becomes the basic content in which information about an artist flows. As a result, experts in digital curation (compilation) are needed.

In the interview, Kasa Gallery manager Derya Yücel states that the most common problems faced by galleries are financial resources and human resources needed for digitalization. Galleries need people who specialize in digital technology.

\section{Findings and discussion}

Table 3 shows the new business models that the interviewed institutions consider necessary in the digitalization processes. There is an important situation that Kasa Gallery Manager Derya Yücel pointed out during her

\section{Table 3}

The new business lines that Contemporary Art Museums and Galleries need in their digitalization processes

\begin{tabular}{|c|c|}
\hline KG & $\begin{array}{l}\text { IT department } \\
\text { A new area of expertise where art and digital space combine }\end{array}$ \\
\hline PWG & $\begin{array}{l}\text { Social Media Expert } \\
\text { Piar and Digital Manager }\end{array}$ \\
\hline PM & $\begin{array}{l}\text { A hybrid business model where physical access in the office is blended with digital/virtual Access } \\
\text { A hybrid business model where physical access on an activity basis is blended with digital/virtual Access } \\
\text { Business models that make remote working possibly with digital access }\end{array}$ \\
\hline A.R.T & $\begin{array}{l}\text { People specialized in photography, video, and graphics } \\
\text { People who have graduated from visual departments of universities, and high schools in } \\
\text { the field of culture and arts, broadcasting and similar creative sectors and have experience } \\
\text { in branches such as television broadcasting, design, cinematography }\end{array}$ \\
\hline ZBG & Publishing service is constantly taken from online art organizations \\
\hline BRSN & $\begin{array}{l}\text { Business models needed for the presentation of exhibitions and works Business models needed in commercial activities } \\
\text { Business models needed for digital communication } \\
\text { Works providing technological services for the experience of products that can only be shown visually on } \\
\text { the Internet in virtual tour format and for exhibitions experienced with AR and VR technologies } \\
\text { Jobs giving support for integrating voice guidance apps into mobile devices } \\
\text { Sectors that organize communication and marketing content due to their difference } \\
\text { in the number of social media and the content structures they offer }\end{array}$ \\
\hline RTON & $\begin{array}{l}\text { Social Media Management } \\
\text { e-commerce site expertise }\end{array}$ \\
\hline AKS & Communication experts on digital platforms \\
\hline ELG & $\begin{array}{l}\text { Social Media Expert } \\
\text { Expert in web design }\end{array}$ \\
\hline BKS & $\begin{array}{l}\text { Competent and foreign-speaking personnel in the digital world } \\
\text { A workshop that provides digital information and training in and out of the institution }\end{array}$ \\
\hline
\end{tabular}


interview. Yücel states that experts are also expected to be trained in art management. Three of the institutions participating in the study pointed out that the digital technology experts needed in contemporary art museums and galleries should also be experts in the field of art and have academic training. Almost all of the contemporary art museums and galleries (8/10) participating in the interview desired the management of the networks they use in the communication function and their web designs to be organized by people who are competent in digital technology. Two people who participated in the interview stated that e-commerce experts are needed and expressed their desire that digital marketing content should be prepared by people who are competent in e-commerce. One institution participating in the interview remarked on its reception of online publishing services from outside. A museum manager who participated in the interview emphasized the importance of digital literacy and underlined the need to organize workshops to increase digital literacy inside and outside the institution.

The preservation and conservation of time-based contemporary artworks is an area that should consist of more featured and diverse components. Time-based media and digital art are characterized as artworks of a certain duration, including film, video, digital, audio, computer-based, web-based, performance, and installation art (Smithsonian Time-based Media \& Digital Art, n.d.). These artworks consist of technology-based components that present specific challenges for preservation, documentation, placement, and purchasing. According to Glenn Wharton (2013) who served as a conservator at the Museum of Modern Art in New York between 2007 and 2013 and established a time-based media preservation program for video, performance, and software-based collections in the museum time-depended and digital artworks may change with each installation (Sanchez \& Smith, 2013). Thus, it is important to document the stages of installation. In this way, the next generation of museum staff can use these documents to decide or at least know how it was established at different points throughout history. Including the artist's comments, whole details of the installation should be recorded, involving floor plans and wall surfaces for the exhibition, paint or carpet types, light levels, sound levels, and room size. This information should be located somewhere in the collection management database.

One of the interviewed institutions has articulated the emerging business model related to time-based media and digital art preservation and conservation as a new area of expertise that combines art and the digital field. One interviewer has described it as a hybrid business model in which physical access on the basis of events is blended with digital/virtual access. An interviewer has expressed it as the business model needed for the presentation and installation of exhibitions and works. The same interviewer has asserted that there is a requirement for business models that provide technological services for the works available to be shown on the internet to be experienced in virtual tour format and for the exhibitions experienced with AR and VR technologies.

\section{Conclusion}

In studies on new business models led by digitalization in contemporary art museums and galleries, it has been observed that museums and galleries require business models in three realms. These three subjects are related to the functions of contemporary museums and galleries gathered in three sections: preservation, research, and communication. Digital curation (compilation) can be considered as a business area that encompasses all three functions.

One of the crucial results arising from practice is; in museums and galleries, it is necessary to combine expertise in technology with art management education. This should be covered by digital strategies for new business models. It is necessary to specialize in IT and to recognize new areas of expertise that will combine technology and art disciplines in addition to emerging business models. For this, the need for academic education processes should also be taken into account.

The need for social media managers, who manage the web pages of these institutions and prepare content for digital platforms, in contemporary art museums and galleries has increased. However, it has become a necessity for these areas to consist of people who have received art education. The reason for this can be seen in the necessity that technology should not alienate the aura that art generates. Digital technology is necessary for a contemporary museum and gallery, but it should not prevent the perception of the art object and the unique aura that only its materiality can produce. For instance, the selection of digital technologies utilized for exhibition and communication purposes in institutions should be made by people who can construe works of art and know technology. In fact, what art institutions need is a technology that exists but is invisible. This technology should be a responsive one that can respond in different ways depending on its utilizer.

Conservators, curators, and staff who are responsible for the organization of exhibitions should not only be experts in theory and ethics in their fields but should also be deeply in touch with the material aspects of the work. This knowledge and experience are especially important in an exhibition of time-dependent and digital artworks, which require installation.

The aura of being physically confronted with the artwork/movements may require contemporary art 
institutions to remain in a more integrated and hybrid space. Contemporary art institutions should invest in this area, anticipating that digital and physical interaction will cover a growingly integrated field. Within this regard, one of the strategies to be made is training that will strengthen digital literacy in institutions.

The digitalization needs of museums and galleries and the special situations arising from the existence of art have created new diverse business models that requisite digital skills. The interdisciplinarity of contemporary museology and galleries will continue to fabricate emerging business models that are constantly evolving in the fields of education/training, ICT, management strategic areas, exhibition design, and communication. As a strategic approach, developing new business models in consonance with the requirements and variability in the digitalization process in contemporary art institutions may be essential for the continuity of institutions.

\section{References}

Bakbaşa, C. \& Plancisi, Y. Ş. (2010) Istanbul'un Kültür Ekonomisindeki Gelişen Sektörlerden Biri: Görsel Sanatlar. Istanbul, Turkey, İstanbul Kültür Mirası ve Kültür Ekonomisi Envanteri. Available from: https:// docplayer.biz.tr/2607685-Istanbul-kultur-mirasi-ve-kultur-ekonomisi-envanteri-2010-istanbul-un-kultur-ekonomisindeki-gelisen-sektorlerden-biri-gorsel-sanatlar.html [Accessed 24th March 2021].

Belenioti, Z. C. \& Vassiliadis, C. A. (2017) Branding in The New Museum Era. In: Androniki, K., Damianos, P. \& Petros, S. T. (eds.) Strategic Innovative Marketing. Switzerland, Springer, pp. 115-121. Available from: doi: 10.1007/978-3-319-33865-1 14

Birol, Ö. (2018) Pera Müzesi Özelinde Müzecilik ve Pazarlama. Değer Üreten Müzeler: Pazarlama Stratejileri. Müzecilik Seminerleri: iletişim Odakıı Müzeler. [Video] Available from: https://www.youtube.com/watch?v=LOmHRmVdgVs\&t=669s [Accessed 24th March 2021].
Bunting, L., Allison, V. \& Handler, B. L. R. (2014) Art Gallery Archives: Professionalization of a Commercial Sector. Journal Of The Art Society Of North America. 3 (1), 81-94. Available from: doi: 10.1086/675708

Erbay, M. (2017) Yeni Nesil Teknolojiler ile Müzede Eğitim. Milli Eğitim. 46 (214), 255-268.

Karadeniz, C. (2018) Müze Kültür Toplum. Ankara, Turkey, Imge Kitabevi Yayınları.

Krebs, A. (2016) Museum of The Future Insights and reflections from 10 international museums. Available from: http://www. project-musa.eu/ wp-content/uploads/2017/03/MuSA-Museumof-the-future.pdf [Accessed 24th March 2021].

Morrison, A. (2019) Digital Strategy For Museums. Available from: https://www.cogapp.com/digital-strategy [Accessed 24th March 2021].

Mu.SA - Museum Sector Skills Alliance. (2017) Emerging Job Profiles for museum professionals. Available from: http://www. project-musa.eu/wp-content/uploads/2020/06/ MuSA-Emerging-Job-Profiles-for-museum-professionals. pdf [Accessed 24th March 2021].

Price, K. (2014) How can technology improve the museum experience?. Available from: https://www.vam.ac.uk/ blog/digital/how-can-technology-improve-the-museum-experience [Accessed 24th October 2021].

Resch, M. (2018) Management Of Art Galleries. London, United Kingdom, Phaidon Press Limited.

Taymaz, E. (2018) Dijital Teknolojiler ve Ekonomik Büyüme Dijital Teknoloji Sektörlerinde Türkiye'nin Konumu, Fırsatları, Seçenekleri. Istanbul, Turkey, TüsiAD.

Yıldııı, A. \& Şimşek, H. (2006) Sosyal Bilimlerde Nitel Araştırma Yöntemleri. Ankara, Turkey, Seçkin Yayıncılık.

Sanchez, C. \& Smith, J. (2013) Interwiew Glenn Wharton. Smithsonian Time-based Media \& Digital Art. Available from: https://www.si.edu/tbma/interview/interview-glenn-wharton [Accessed 10th October 2021].

Smithsonian Time-based Media \& Digital Art (n.d.) Interviews. Available from: https://www.si.edu/ tbma/interviews [Acsessed 24th March 2021].

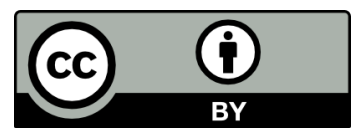

(C) 2022 Authors. Published by the University of Novi Sad, Faculty of Technical Sciences, Department of Graphic Engineering and Design. This article is an open access article distributed under the terms and conditions of the Creative Commons Attribution license 3.0 Serbia (http://creativecommons.org/licenses/by/3.0/rs/). 